\title{
Attitude of Class Teachers to Students with Autism in Inclusive Education Primary Schools
}

\author{
Indina Tarjiah, Istiqomah Riyanti \\ Universitas Negeri Jakarta, Indonesia \\ Email: Indina.tarjiah@gmail.com
}

\begin{abstract}
This research aims to determine the attitudes of classroom teachers to autistic students in the inclusive primary schools. The method used is survey research with the population of 15 inclusive primary schools in Bekasi. The samples of this research are classroom teachers from 4 inclusive primary schools. Data collection techniques were carried out using a questionnaire. Data were analyzed using simple descriptive statistics. The results showed that $71 \%$ of the teachers have good attitudes, $29 \%$ have very good attitudes towards autistic students in inclusive primary schools in Bekasi. If the condition of this good attitude continues to be evenly distributed and comprehensive, it can make inclusive education in the city of Bekasi run well and successfully.
\end{abstract}

Keywords: Attitudes, Classroom Teachers, Autism Students. Inclusive Education Primary School

\section{INTRODUCTION}

The quality of teaching staff in inclusive schools has become a fundamental problem because data in the field found that teachers in inclusive schools have a background in general education. This creates problems in the teaching and learning activity due to lack of knowledge and skills of teachers in dealing with children with special needs. The most critical thing in inclusive education is the readiness of schools in implementing the inclusive education itself. One of which is the teachers' attitudes toward students in schools that provides inclusive education.

The teacher's attitude dramatically determines the success of the implementation of inclusive education because with the right attitude in accepting children with special needs, the teachers will meet the needs of their students optimally by adjusting their needs and abilities in the class. Classroom teachers in inclusive schools are very influential in providing education services for students with special needs. There are teachers who give positive responses in accepting autism children in class by making learning programs that are appropriate to the abilities and needs of students, being fair to all students without discriminating one another, and helping to make learning media and teaching materials in accordance with the ability of autistic students.

However, there also those who give negative responses to autistic students by ignoring them in the classroom so that their learning objectives are not achieved and giving unfair treatment by generalizing the curriculum used by regular students without decreasing the minimum score for these autistic students. With different characteristics and abilities, it is necessary to create special program for autistic students in schools that provide inclusive education in order to achieve their learning goals which are in accordance with their abilities and needs.

From the results of research conducted by Popon Patimah entitled "The Attitudes of Teachers Against Students with Autistic Disorders" in East Jakarta in 2016, it was found that the attitude of teachers towards students with autistic disorders in schools with inclusive education in East Jakarta is already good. The implementation of conducive environment in the teaching and learning process can help autistic students to be able to socialize in the surrounding environment.

Because there have been many studies conducted in Jakarta, the researchers are interested in re-examining the classroom teacher's attitude towards autism in different places with more reliable informants. Researchers conducted different studies and make the classroom teachers in inclusive schools to be the trusted informants. Researchers surveyed Bekasi city where there are 10 schools registered in Education Office of Bekasi as schools which provide inclusive education.

When comparing the findings in the field with the results of a survey conducted by Popon Patimah in 2016, the researchers were interested in proving whether the attitudes of class teachers towards autistic students are getting better or not because the survey by Patimah Popon in 2016 actually showed good results. In this research, the researchers took part in collecting data as a source of information in evaluating the quality of the implementation of inclusive education in Bekasi. The research would observe the attitude of class teachers to autistic students in Bekasi. Therefore, 
the problem of this research was: how is the attitude of class teachers towards autistic students in Inclusive Primary Schools in West Bekasi District, South Bekasi District, Jatiasih Subdistrict, and Pondok Gede District, Bekasi City?

The current research has the following objectives: For schools: a) To find out the attitude of class teachers to autistic students in Inclusive Schools in West Bekasi District, South Bekasi District, Jatiasih Subdistrict, and Pondok Gede District, Bekasi. b) As a reference data for schools to increase their knowledge as Inclusive Schools in West Bekasi District, South Bekasi District, Jatiasih Subdistrict, and Pondok Gede District, Bekasi.

For teachers: a) As a reference data for educators to increase their knowledge about the attitudes to autistic students in Inclusive Schools in West Bekasi District, South Bekasi District, Jatiasih District, and Pondok Gede District Bekasi. For researchers: a) To know the facts about the attitude of class teacher towards autistic students in inclusive schools in West Bekasi District, South Bekasi District, Jatiasih District, and Pondok Gede District, Bekasi, b) As reference data for prospective educators before entering the Inclusive Schools in West Bekasi District, South Bekasi District, Jatiasih Subdistrict, and Pondok Gede District Bekasi. For Special Education Students: a) To provide knowledge for students so that they better understand the attitude of class teachers towards autistic students at the Inclusive Schools in West Bekasi District, South Bekasi District, Jatiasih Subdistrict, and Pondok Gede Subdistrict, Bekasi.

Everyone has a different attitude towards certain things (individual objects). Attitude shows judgment, feeling, and action towards an object. Different attitudes occur because of the understanding, experience, and consideration that someone has experienced in an object. Therefore the results of attitudes towards an object are definite (accepting) and negative (not accepting).

According to Sarwono (2009), attitude is a term that reflects the feeling of pleasure, displeasure or the feeling of mediocrity of someone towards "something". This "something" can be an object, events, situations, people, or groups. Krech, Crutchfield, and Ballachey formulated three components such as cognitive components, feeling components, and action tendencies. The cognitive component is a person's trust in an object; therefore a trust depends on whether or not it is pleasant or beneficial and about how to respond accordingly to an object. The feeling component is measured experimentally. The results will show whether an object is perceived as pleasant or not. Components of action tendencies refer to the tendency of a person's actions, both positive and negative towards the object of attitude (Sobur, 2003). Based on the information described above, the researchers conclude that there are 3 components of attitude, namely the cognitive component related to the thought of knowledge and trust, the active component of real feelings shown to the object, and the conative component which refer to the action on an object.

Attitude formation occurs because of the social interaction experienced by individuals. In social interaction, there is a mutual relationship that influences individuals and others, and there is a reciprocal relationship that also influences the behavior patterns of each individual as a member of the society (Azwar, 2015). Azwar quotes Katz's opinion which explains four attitudes functions, namely: (a) The function of self-adjustment which means the attitude of trying to maximize the things that are desired and minimizing things that are not desirable; (b) The function of ego defense protecting against the bitter reality which is an attitude that can reflect personality problems that are not resolved; (c) The function of expression of values which means that attitudes help positive expressions of one's fundamental values, show off his/her image, and actualize him/herself; (d) The function of knowledge which means the attitude as a scheme, namely a way of structuring so that the world around looks logical and reasonable. This attitude is used to evaluate existing external phenomena and organize them. (Azwar, 2015).

Teachers as professionals at primary education and secondary education are evidenced by an educator certificate. Class teacher is someone who leads, organizes, and provides educational services for students in their class. According to the Government Regulation No. 74/2008 concerning Teachers, teachers are professional educators with the primary task of educating, teaching, guiding, directing, training, evaluating, and evaluating students in formal education, primary education and secondary education (Supriyadi, 2013).

Understanding the teacher can be done by comprehending Law No. 14 of 2005 concerning teachers and lecturers which declares that national development in the field of education is an effort to educate the life of the nation and improve the quality of Indonesian people to be faithful, pious, and noble and acquire the knowledge in science and technology, to be an advanced, just, prosperous society, and to be civilized individuals based on Pancasila and the 1945 Constitution of the Republic of Indonesia. It is concluded that a classroom teacher is a teacher who is appointed by the principal and has the task and responsibility to teach, educate, and guide students in order to develop academic and non-academic potential in a classroom during the learning process.

In schools that provide inclusive education, educators or teachers consist of classroom teachers, subject teachers, and individual tutors. Teachers in 
inclusive schools are teachers with a general education background. They are not prepared to educate children with special needs. It is very possible that they have difficulties to overcome problems in a class with special needs children. Therefore, individual tutors are available in inclusive schools (Garnida, 2015). The main tasks of a teacher are as follows: (1) Mastering teaching materials; (2) Implementing teaching and learning programs; (3) Implementing, leading, and managing the teaching and learning process, and; (4) Assessing learning activities.

The roles of a teacher are as follows: (1) As a facilitator who facilitates students in teaching and learning activities; (2) As a mentor who helps students to overcome problems in the learning process; (3) As communicators who communicate with students and the community; (4) As a model who provides good examples so that students behave well; (5) As evaluators who assess the development of their students both affective, cognitive, and psychomotor; (6) As innovators who also disseminate renewal efforts to the community; (7) As cognitive agents who share knowledge, and; (8) As managers who lead groups of students in the classroom so that the learning process successful.

However, classroom teachers in inclusive schools have other tasks including: creating a conducive learning climate so that children feel comfortable learning in class / school, compiling and carrying out assessments for all children to know their abilities and needs, preparing individual learning programs (PPI) together with special education teachers, carrying out teaching and learning activities and conducting assessments for all subjects under their responsibility, providing teaching remedial programs, enrichment / acceleration for students in need, and carrying out classroom administration in accordance with their duties. (Garnida, 2015).

In a book written by Ilahi (2016), teachers, as a component in the learning system to improve students' abilities, has an important role in determining the direction and purpose of a learning process. Therefore, a teacher is required to master some abilities and skills related to the learning process, including the ability to master teaching materials, the ability to manage classes, the ability to use methods, media, and learning resources, and the ability to make evaluations, both the processes and the results. These teacher's abilities should meet the learning principles that have been set by UNESCO as the four pillars of learning.

The role of classroom teacher is very important in the development of their students, so that teachers are required to meet their learning objectives, especially for students with special needs. According to the Ministry of National Education in 2002, Autism is a complex developmental disorder involving communication, social interaction, and imagination activities. Autistic children also have problems in the fields of communication, social interaction, sensory disorders playing patterns, and emotions (Supena, 2015).

Prasetyono (2008) explained that autism is a collection of syndromes that interferes the child's developmental nerves, the diagnosis known from the visible symptoms and indicated by the developmental deviations, such as social interaction, language and communication which exist or are repeated by individuals with autism. It can be concluded from the provided understandings, that children with autism are children who experience disturbances in the brain so that they experience delays in various aspects of development such as language and communication, social interaction, and stereotyped behavior. These delays can be seen during childhood development starting from 0-3 years old.

Autistic children are characterized by several disorders such as: (a) Social interaction, including rejecting or avoiding face to face or eye contact; (b) Communication, including speech, language, and communication, such as echolalia (imitating or parroting), communicating with body language, etc; (c) Disruption in playing, for example playing monotonously and strangely, such as playing tires on cars and watching them for a long time; (d) Sensory disorders, including feeling sensitive to something, such as touch, hearing, light, taste (tongue) or smell; (e) Feelings and emotions, such as laughing or crying suddenly, even angrily with no cause; (f) Behavioral disorders, such as hyperactivity or even very quiet, do not like change, repeat a particular movement such as walking back and forth, running endlessly, etc.

Yuwono (2009) in his book revealed some of the characteristics of autistic children that can observed as follows: a) Behaviors such as: indifference to the environment, undirected behavior; going back and forth; run; fierce; circling; jumping, etc., attachment to a particular object, rigid routine, tantrum, obsessivecompulsive behavior, and fascination with rotating objects or moving objects, b) Social interactions such as: not looking at the eyes, not responding when called, not wanting to play with their peers, playing by themselves, no empathy with the social environment, c) Communication and language such as speech delay, no effort to communicate non-verbally with body language, not understanding language, echo (echolalia), and not understanding other people's speech. 
Table 1. List of Bekasi City Inclusive Education Supporting Schools

\begin{tabular}{|c|c|c|c|}
\hline No & Name of School & Information & $\begin{array}{l}\text { Total } \\
\text { number of } \\
\text { teachers }\end{array}$ \\
\hline 1. & SDN Jatimekar I & Jati asih & 20 \\
\hline 2. & $\begin{array}{l}\text { SDN Bantar ge- } \\
\text { bang IV }\end{array}$ & $\begin{array}{l}\text { Bantar ge- } \\
\text { bang }\end{array}$ & 14 \\
\hline 3. & $\begin{array}{l}\text { SDN kali baru } \\
\text { IV }\end{array}$ & $\begin{array}{l}\text { Medan sa- } \\
\text { tria }\end{array}$ & 14 \\
\hline 4. & $\begin{array}{l}\text { SDN Jatiwar- } \\
\text { ingin III }\end{array}$ & $\begin{array}{l}\text { Pondok } \\
\text { gede }\end{array}$ & 14 \\
\hline 5. & SDI Iqro & $\begin{array}{l}\text { Pondok } \\
\text { Gede }\end{array}$ & 33 \\
\hline 6. & $\begin{array}{l}\text { SDS Permata } \\
\text { Ananda }\end{array}$ & $\begin{array}{l}\text { South } \\
\text { Bekasi }\end{array}$ & 9 \\
\hline 7. & SDS YPI ‘ 45 & East Bekasi & 18 \\
\hline 8. & $\begin{array}{l}\text { SDS Royal Weis } \\
\text { (Mutiara Indo- } \\
\text { nesia) }\end{array}$ & $\begin{array}{l}\text { West } \\
\text { Bekasi }\end{array}$ & 14 \\
\hline 9. & $\begin{array}{l}\text { SDS Citta } \\
\text { Bangsa }\end{array}$ & Jati Asih & 10 \\
\hline 10. & SDS Al Izzah & $\begin{array}{l}\text { Medan Sa- } \\
\text { tria }\end{array}$ & 15 \\
\hline 11. & $\begin{array}{l}\text { SD Islam Al } \\
\text { Fajri }\end{array}$ & Pekayon & 12 \\
\hline 13. & $\begin{array}{l}\text { Sekolah Batutis } \\
\text { Al-ilmi }\end{array}$ & Pekayon & 16 \\
\hline 14. & $\begin{array}{l}\text { SDIT Darus- } \\
\text { salam }\end{array}$ & Cikunir & 36 \\
\hline 15. & $\begin{array}{l}\text { Sekolah Shib- } \\
\text { ghah Akhlak } \\
\text { Quran (Sakura) }\end{array}$ & Jakamulya & 20 \\
\hline Total & & & 245 \\
\hline
\end{tabular}

Minister of National Education Regulation number 70 of 2009 concerning Inclusive Education defines inclusive education as an educational system that provides opportunities for all students who have physical abnormalities and has the potential for intelligence and / or unique talents to attend education or learning in an educational environment together with students in general (Mudjito, Harizal, \& Rimilton 2014)

According to Stainback, schools that provide comprehensive individual education should accommodate all students in the same class. Schools must provide educational programs that are feasible, challenging, but adaptable to the abilities and needs of each student (Mudjito, Harizal, \& Rimilton 2014).
From the various notions of inclusive education above, the researchers conclude that inclusive education organized by regular schools that accept students with special needs to study with regular students aims at facilitating students to get education services which are far from their place of residence. Moreover, schools also adjust curriculum programs and infrastructure to support the abilities and needs of students with special needs.

In a book entitled Inclusive Education Concepts and Applications, there are several things that need to be examined further about the objectives of inclusive education, namely (a) providing the broadest opportunity for all students who have physical, emotional, mental and social disabilities or have exceptional intelligence and / or talent to obtain quality education according to their needs and abilities; (b) realizing the implementation of education that respects diversity, and not discriminatory for all students Ilahi (2016).

In organizing inclusive education there several essential components that must be considered, namely: (1) Curriculum flexibility (teaching materials). the curriculum includes objectives, materials, learning strategies, media and learning evaluation that must be modified according to the abilities and needs of students with special needs; (2) Educators (teachers) are expected to fulfill qualification requirements such as having the ability, skills, and attitudes about the material that are taught, as well as understanding the characteristics of students; (3) The input of students. It is expected that the schools would have information about the initial ability, data, and characteristics of students with special needs in order to assist teachers in designing and implementing learning objectives optimally; (4) Environment and the implementation of inclusive schools. The collaboration between parents, teachers, schools and also the government in building a friendly environment for students with special needs is a critical role. In this case, the government has the role of providing special teachers, as well as budgets that help schools in optimizing the implementation of inclusive education; (5) Facilities and infrastructure affect the implementation of inclusive education. Therefore, it is essential that there are adequate facilities and infrastructure that facilitate students in inclusive schools.

\section{METHODS}

This is a quantitative research using survey methods. Survey method is the best method to obtain data and to collect original data from respondents to describe the state of the population. 
Table 2. Overall Statistics Description

\begin{tabular}{cccccc}
\hline & $\begin{array}{c}\text { Aver- } \\
\text { age }\end{array}$ & $\begin{array}{c}\text { Me- } \\
\text { dian }\end{array}$ & $\begin{array}{c}\text { Mo- } \\
\text { dus }\end{array}$ & $\begin{array}{c}\text { Skor } \\
\text { Mak }\end{array}$ & $\begin{array}{c}\text { Skor } \\
\text { Min }\end{array}$ \\
\hline Total & 121.4 & 120 & 113, & 150 & 30 \\
& & & 114, & & \\
& & & 119, & & \\
& & & 121, & & \\
Cognitive & 42.45 & 41 & 40,41 & 55 & 11 \\
Affective & 44.17 & 45 & 45 & 50 & 10 \\
Conative & 35.2 & 35 & 34 & 45 & 9 \\
\hline
\end{tabular}

Table 3. Distribution of Frequency of the Overall Attitudes of the Respondents

\begin{tabular}{ccc}
\hline Interval class & Frequency & Information \\
\hline $30-53$ & 0 & Very bad \\
$54-77$ & 0 & Not Good \\
$78-101$ & 0 & Enough \\
$102-125$ & 25 & Good \\
$126-149$ & 10 & Very Good \\
\hline
\end{tabular}

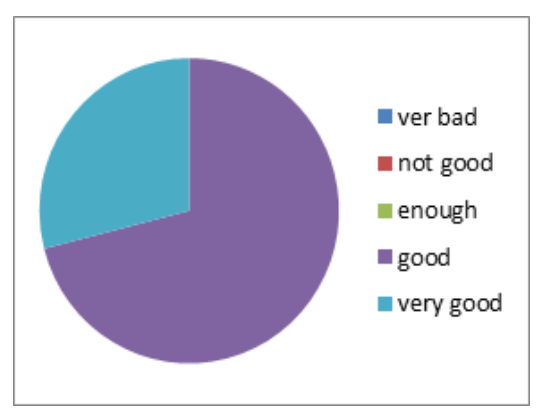

Figure 1. Graph of Classroom Teacher's Attitude to Autistic Students

The purpose of this research is to find out the empirical data about the attitudes of class teachers to autistic students in Inclusive Primary Schools in West Bekasi District, South Bekasi District, Jatiasih Subdistrict, and Pondok Gede District, Bekasi. The research was conducted at the Inclusive Primary School in West Bekasi District, South Bekasi Subdistrict, Jatiasih Subdistrict, and Pondok Gede Subdistrict in Bekasi area where autistic students are found. This research was conducted for seven months, starting from December 2017 to July 2018. The population in this research was all classroom teachers who taught autistic students in Inclusive Primary Schools in Bekasi who are included the following table 1.

The selection of the subject of this research used a purposive sample. The researchers determine the research subjects by having a specific purpose. Researchers then provided questionnaires only to classroom teachers who teach autistic students in inclusive schools. Some schools / teachers that were studied include: 7 teachers of Royal Well School in Bekasi Barat sub-district, 8 teachers of Jatiwaringin III Elementary School in Pondok Gede sub-district, 10 teachers of Jatimekar I Elementary School in Jatiasih sub-district, and 10 School teachers Shibghah Akhlak Qur \& rs in the South Bekasi sub-district where autistic students are found.

Data analysis techniques were carried out using descriptive statistical analysis. Descriptive statistics is used to analyze data by describing the collected data and then drawing conclusions from the research objectives and limiting the problems that have been decided. The steps in the data analysis technique are: a) identifying the highest and lowest scores of the respondents, b) finding the average score from the number of scores obtained, c) searching for the median, d) searching for the mode. After that, it was analyzed to conclude whether the attitude of teachers towards autistic children in inclusive primary schools is good. Also, the results of the data analysis were described and then drawn as a conclusion.

\section{FINDINGS AND DISCUSSION}

\section{Findings}

The data of this study were obtained from 35 respondents who are classroom teachers in inclusive schools with autistic students in Bekasi. Data was presented as a whole in the form of frequency distribution tables consisting of averages, standard deviations, medians, modes, maximum scores, minimum scores, and circle graphs. The description of the data on the attitudes of the class teacher towards autistic students in inclusive schools was integrated with the respondents as a whole from 4 schools which also provide inclusive education in Bekasi. The information can be seen in the table 2 .

Based on the table 3 is known that out of 35 respondents in total, there are 25 respondents obtained the highest score in the range of $102-125$ which means the attitude of the class teacher to students with autism is good. Other 10 respondents who obtained a score of 126 - 149 are considered very good to students with autism. If described in the diagram, the distribution show in figure 1.

The data was obtained from 35 respondents who are the classroom teachers in 4 inclusive schools in the city was associated with 30 items of statements regarding the attitude of class teachers towards autistic students. There are $25(71 \%)$ respondents stated that the attitude of the class teacher to autistic students in inclusive schools is good. As many as 10 (29\%) of respondents stated the attitude of the classroom teachers is very good to autistic students in inclusive schoolsin 
Bekasi, and no $(0 \%)$ respondents said that they are not good nor good enough to autistic students in inclusive schools in Bekasi.

This can give an idea that the attitude of classroom teachers to the autistic students is in the excellent category $(71 \%)$. Therefore, it can be concluded that from the overall results the class teacher already reacts well to the thoughts, feelings, and actions in accepting or rejecting the autistic students in the inclusive schools in Bekasi.

\section{Discussion}

The findings of the survey have clearly showed that most classroom teachers in Bekasi who conduct inclusive education to students with autism have possitive attitudes to the students. The results of this research are similar to the results of other researches within similar topic in which teachers generally held good gestures to their students with autistic disorder (Ross-Hill, 2009; Park \& Chitiyo, 2011; Engstrand \& Roll-Pettersson (2014).

However, contrary results were also found in other reseraches of the same issue. Alamri and TylerWood (2016) noticed that teachers in Saudi prefered to teach students with autism separately and not in inclusive environment. In addition, Cassady (2011) also noted that teachers expressed their concerns of not being able to teach students with autism and emotional behavioral disorders. To overcome and prevent other negative attitudes of teachers to students with autism in an inclusive setting, there should be a clear guidance and regulation for educaional institutions. Symes and Humphrey (2011) suggested that factors inclusing access to expertise, communication within school, and teaching staffs awareness of students autism should be taken into consideration in order to run the teaching and learning activities appropriately.

\section{CONCLUSION}

Based on the results of the research from 4 inclusive schools in West Bekasi District, South Bekasi Subdistrict, Jatiasih Subdistrict, and Pondok Gede Subdistrict, Bekasi, the class teachers in teaching autistic students already reacts well to the thought, feeling and action in accepting or rejecting the autistic students in inclusive schools in West Bekasi District, South Bekasi District, Jatiasih Subdistrict, and Pondok Gede District Bekasi, especially on the affective dimension of the attitude of teachers to autistic students in inclusive schools.

From these conditions, it can be interpreted that the classroom teachers in inclusive schools in West Bekasi Subdistrict, South Bekasi Subdistrict,
Jatiasih Subdistrict, and Pondok Gede Subdistrict in Bekasi region already have an appropriate reaction in evaluating the aspects in their social environment which are a collection of reactions from feelings, thoughts, and actions that are consistently good for autistic students in the inclusive school.

In the cognitive dimension, the classroom teachers are good at understanding the characteristics of autistic students in their class, either the academic aspects, social aspects or emotional aspects. In the affection dimension, the class teachers already have a good emotional response to the existence of autistic students in the classroom who are more concerned with the academic, social and emotional aspects. Likewise, with the conative dimension, the class teachers already have an excellent response to the academic aspects, social aspects, the emotional aspects of the autistic students in their class.

Therefore, it can be concluded that the attitude of class teachers towards autistic students in inclusive schools in West Bekasi District, South Bekasi Subdistrict, Jatiasih Subdistrict, and Pondok Gede Subdistrict, Bekasi is good. The class teachers already have an evaluative reaction to the aspects of their social circle which is a collection of reactions from feelings, thoughts, and actions that are consistent with the autistic students in the inclusive schools.

\section{REFERENCES}

Alamri, A., \& Tyler-Wood, T. (2016). Teachers' Attitudes toward Children with Autism: A Comparative Study of the United States and Saudi Arabia. The Journal of International Association of Special Education, 16, 14-25.

Azwar, S. (2015). Sikap Manusia Teori dan Pengukurannya. Yogyakarta: Pustaka Pelajar.

Cassady, J. M. (2011). Teachers' attitudes toward the inclusion of students with autism and emotional behavioral disorder. Electronic Journal for Inclusive Education, 2(7), 1-23.

Engstrand, R. Z., \& Roll-Pettersson, L. 2014. Inclusion of Preschool Children with Autism in Sweden: Attitudes and Perceived Self Efficacy in Preschool Teachers. Journal of Research in Special Educational needs, 14(3), 170-179.

Garnida, D. (2015). Pengantar Pendidikan Inklusif. Bandung : PT Refika Aditama.

Ilahi, M. T. (2016). Pendidikan Inklusif Konsep dan Aplikasi. Yogyakarta: Ar- Ruzz Media.

Mudjito, E., Harizal., \& Rimilton, R. (2014). Pendidikan Layanan Khusus: Model-Model dan Implementasi. Jakarta: Baduose Media. 
Park, M., \& Chitiyo, M. (2011). An Examination of Teacher Attitudes towards Children with Autism. Journal of Research in Special Educational needs, 11(1), 70-78.

Prasetyono. (2008). Serba-serbi Anak Autis. Yogyakarta: DIVA press.

Ross-hill, R. (2009). Teacher Attitude towards Inclusion Practices and Special Needs Students. Journal of Research in Special Educational needs, 9(3), 188198.

Sarwono, S. (2009). Pengantar Psikologi Umum. Jakarta: PT Raja Grafindo Persada.

Sobur, A. (2003). Psikologi Umum. Bandung: Pustaka Setia.
Supena, A. (2015). Pengantar Pendidikan Anak Berkebutuhan Khusus. Jakarta: Lembaga Pengembangan Pendidikan UNJ.

Supriyadi, O. (2013). Profesi kependidikan. Yogyakarta: LaksBang Pressindo.

Symes, W., \& Humphrey, N. (2011). School Factors that Facilitate or Hinder the Ability of Teaching Assistants to Effectively Support Pupils with Autism Spectrum Disorders (ASD) in Mainstream Secondary School. Journal of Research in Special Educational needs, 11(3), 153-161.

Yuwono, J. (2009). Memahami Anak Autistik Kajian Teoritik dan Empirik. Bandung: Alfabeta. 